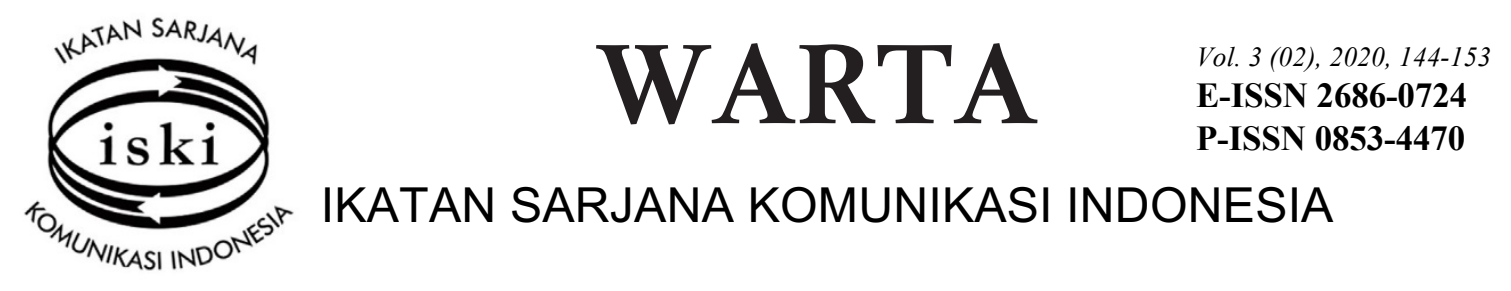

\title{
Pengaruh Motivasi Binge Watching terhadap Behavioral Involvement
}

\author{
https://doi.org/10.25008/wartaiski.v3i02.71
}

\author{
Elsa Indah Libriani ${ }^{1}$, Poppy Ruliana ${ }^{2}$, Kresno Yulianto ${ }^{3}$ \\ ${ }^{1}$ Program Studi Ilmu Komunikasi, Sekolah Tinggi Ilmu Komunikasi InterStudi \\ ${ }^{2,3}$ Magister Ilmu Komunikasi, Sekolah Tinggi Ilmu Komunikasi InterStudi \\ *e-mail korespondensi: elsaalibriani@hotmail.com
}

Submitted: 11/11/2020, Revised: 09/12/2020, Accepted: 19/12/2020

Accredited by Kemristekdikti No. 30/E/KPT/2019

\begin{abstract}
This research discusses binge watching motivation which affect behavioral involvement. Video-on-demand (VoD) services arouse the motivation of service users for binge-watching. Someone will be considered to be a binge watcher if he/she watches two episodes of TV shows or more at a time. Binge watching is a new trend of media consumption due to the higher number of VoD platforms in Indonesia. One of the most popular VoD service providers for TV shows and movies is Iflix. The research approach employed in this study is quantitative with positivism paradigm. This study uses explanative method and the type of research is survey. Data were collected through observation, interviews, documentation and literature review as well as browsing the internet to obtain relevant information. The population of this study comprised 167 students of STIKOM Interstudi majoring in Broadcast in the 2017/2018 academic year. Samples were measured using Issac and Michael formulas so that 105 samples were obtained with a margin of error of $10 \%$. The data analysis technique uses a SEM analysis to test several hypotheses. The results of this research show that enjoyment, efficiency, and escape have a positive impact on attitude to use, continuence to use, and word of mouth, while fandom has no impact on word of mouth and social influence also has no impact on continuence to use.
\end{abstract}

Keywords: motivation; binge watching; behavioral; involvement; media digital

\begin{abstract}
Abstrak
Penelitian ini membahas motivasi binge watching terhadap behavioral involvement. Layanan video on-demand merangsang motivasi pengguna layanan untuk binge-watching. Seseorang dikatakan binge watching jika menonton dua episode TVshows atau lebih dalam sekali waktu. Binge watching menjadi tren baru dalam mengonsumsi media karena banyaknya platform video on-demand di Indonesia. Salah satu penyedia layanan video on-demand yang paling popular untuk TV shows dan film adalah Iflix. Pendekatanan penelitian yang digunakan adalah kuantitatif dengan paradigma positivisme. Metode yang digunakan adalah eksplanatif dan jenis penelitiannya adalah survey. Pengumpulan data dilakukan melalui observasi, wawancara, dokumentasi, tinjauan pustaka serta penelusuran melalui internet untuk memperoleh informasi yang relevan. Populasi penelitian ini adalah mahasiswa STIKOM Interstudi jurusan Broadcast tahun ajaran 2017 dan 2018 berjumlah 167 mahasiswa. Untuk mengukur sample digunakan rumus Issac dan Michael sehingga diperoleh 105 sample dengan tingkat kesalahan 10\%. Teknik analisis data menggunakan analisis SEM untuk menguji beberapa hipotesis. Hasil penelitian menunjukkan, enjoyment, efficiency, escape berpengaruh positif pada attitude to use, continuence to use, dan word of mouth sedangkan fandom tidak memiliki pengaruh terhadap word of mouth dan social influence juga tidak berpengaruh pada continuence to use.
\end{abstract}

Kata Kunci : motivasi; binge watching; behavioral; involvement; media digital

PENDAHULUAN

Perkembangan teknologi informasi tidak dapat dihindarkan dalam kehidupan modern. Teknologi dipancarkan melalui sebuah media yang berfungsi menyalurkan pesan atau infomasi dari sumber ke 
penerima pesan. Terdapat berbagai macam media massa seperti radio, majalah, televisi yang melalui perkembangan teknologi digital saat ini membuat masyarakat beralih ke media baru berbasis internet (Shabrina, 2019). Akibatnya, pengguna internet selalu bertambah setiap tahun. Menurut APJII (Asosiasi Penyelenggara Jasa Internet Indonesia), pada 2018 pengguna internet di Indonesia mencapai 64,8\% dari seluruh penduduk Indonesia, atau setara dengan 171,17 juta jiwa (APJII, 2019).

Bersama internet, hadir istilah new media yang merupakan pernyederhanaan istilah di luar media massa konvensional: televisi, radio, majalah, koran, dan film (Romli \& Syamsul, 2012). Internet memudahkan media massa memproses komunikasi infomasi terhadap khalayak luas. Internet juga memperkenalkan video streaming. Survei pada tahun 2018 menyatakan, pengguna internet di Indonesia 45,3\% menonton film/video (APJII, 2019).

Digitalisasi memperkenalkan layanan Video on Demand (VOD). Layanan VOD memungkinkan pengguna memilih dan menonton video yang diakses dalam jaringan sebagai bagian dari sistem interaktif. VOD memanfaatkan proses streaming dan pengunduhan progresif (Wahanani, Saputra dan Freitas 2018).

Video on Demand mengisyaratkan sebuah fleksibilitas dan penyesuaian kebutuhan berdasarkan kriteria tertentu dengan layanan konten. Layanan VOD sederhananya adalah sistem penyampaian konten video online. Berbeda dengan televisi konvensional, kontennya disiarkan sesuai jadwal tayang. VOD sebaliknya, penonton bisa menikmati dan memilih konten yang dinginkan kapan pun melalui perangkat apa pun. Layanan VOD adalah layanan streaming film berbayar dan non-berbayar.

Menurut penelitian Daily Social.Id ada beberapa situs VOD yang digandrungi masyarakat Indonesia, seperti Netflix, Iflix, Hooq, Viu, Youtube (Eka, 2015). Salah satu penyedia layanan VOD di Indonesia adalah Iflix. Walaupun Iflix bukan market leader untuk layanan VOD tetapi Iflix termasuk dalam jajaran layanan VOD terkemuka di Indonesia.

Iflix diluncurkan di Malaysia dan Filipina, Mei 2015 (Meese, 2016), setahun kemudian Iflix hadir di Indonesia. Sebagai layanan VOD, Iflix menawarkan film digital tanpa iklan, dengan biaya langganan Rp 39.000 perbulan, Rp 9.900 perhari dan Rp 374.400 pertahun untuk tayangan premium. Iflix juga memberikan free streaming untuk beberapa film tertentu $($ Iflix, 2016). Iflix dapat diakses di melalui smartphone, tablet, dan laptop.

Penonton kini tidak lagi terpaku pada jadwal linear televisi, menunggu episode setiap minggunya (Sodano, 2012). Menurut (Stenovec, 2015) sejak tahun 2010 terjadi peningkatan hampir $30 \%$ khalayak melakukan streaming video menggunakan Netflix, Youtube maupun Hulu, dan terjadi penurunan hingga $10 \%$ pengguna TV tradisional dan televisi berbayar. Fakta tesebut menunjukan, penikmat hiburan pada masa kini sudah beralih ke dunia hiburan digital seperti video streaming dibandingkan layanan televisi biasa atau berbayar.

Penelitian ini mengacu pada penelitian Merikivi, Salovaara, Mäntymäki \& Zhang (2017) yang menggunakan variabel Behavioral involvement untuk mengukur sejauh mana pengguna terlibat dalam perilaku binge watching. Hunt, Geiger-Oneto \& Philip (2010) mendefinisikan behavioral involvement sebagai sejauh mana pengguna menggunakan sistem tertentu untuk melakukan sesuatu hal. Pada penelitian ini, suatu hal tersebut adalah binge watching. Penelitian ini difokuskan pada sejauh mana pengguna menggunakan layanan VOD untuk melakukan aktifitas binge watching.

Penelitian Pangestu (2019) menganalisis behavioral involvement pada binge watching. Pola dan kualitas konsumsi media dalam beberapa tahun terakhir berubah secara signifikan karena teknologi, informasi, dan komunikasi. Kemuculan smartphone dan stabilitas internet yang dapat mengirimkan konten media di mana saja dan kapan saja, memungkinkan pemirsa melakukan binge watch (menonton secara marathon/menonton lebih dari dua episode dalam sehari) program favorit mereka melalui streaming online (Hirsen, 2015).

Binge watching adalah fenomena baru yang memungkinkan pemirsa menonton acara televisi kapan saja (Pena 2015). Arti binge watching adalah pesta menonton atau marathon menonton. Menurut Merikivi, Salovaara, Mäntymäki \& Zhang (2017), menonton dua episode TV shows atau lebih dalam sekali waktu diartikan sebagai kegiatan binge watching. Munculnya Iflix dan layanan berdasarkan permintaan terus memicu binge watching (pesta menonton). Mengutip penelitian (Griffee, 2013) mengenai Netflix, binge-watching shift TV-viewing habits, remaja cenderung melakukan binge watching, daripada orang dewasa. Hal ini karena remaja memiliki waktu luang yang banyak dan belum berumah tangga ataupun bekerja (Wagner, 2016). 
Ada sejumlah penelitian membahas binge-watching. Penelitian Shim \& Kim, (2018): An Exploration of the Motivations for Binge-Watching TV Dramas among South Korean Viewers and the Role of Individual Differences, mengatakan ada empat motivasi yang membuat seseorang memutuskan melakukan binge watching yaitu enjoyment, efficiency, fandom dan recommendation of others, tetapi hanya tiga (enjoyment, efficiency, dan fandom) yang terbukti memotivasi seseorang melakukan binge watching.

Penelitian Pangestu (2019) menyempurnakan penelitian Shim dan Kim, dengan menambahkan variabel behavioral involvement untuk melihat sejauh mana pengguna Netflix menggunakan layanan VOD untuk binge watching. Selain itu Pangestu juga menambahkan konsekuensi dari perilaku binge watching, yaitu satisfaction, attitude to use, word of mouth intention, dan continuence to use. Melengkapi dua penelitian sebelumnya, Susanno, Phedra\& Murwani (2019) dalam penelitian The determinant factors of the intention to spend more time binge-watching for Netflix Subscriber in Jakarta, menyatakan faktor penentu niatan seseorang menghabiskan lebih banyak waktu untuk binge watching adalah social influence dan escape.

Variabel tersebut terbukti berpengaruh pada niatan seseorang menghabiskan lebih banyak waktu untuk binge watching. Berangkat dari temuan-temuan tersebut, penelitian ini bertujuan untuk mengetahui pengaruh motivasi binge watching terhadap behavioural involvement pada Iflix guna membuktikan adanya pengaruh antara motivasi binge watching terhadap behavioral involvement pada layanan video on-deman iflix.

\section{KERANGKA TEORI}

Motivasi dapat diartikan sebagai dasar dari pembentukan keterlibatan individu dengan kegiatan produk hiburan (Pangestu, 2019). Binge watching bukanlah fenomena yang hanya didorong oleh teknologi saja, tetapi faktor penonton juga menentukan perilaku menonton. Definisi binge watching sering berubahubah tetapi binge watching menawarkan pengalaman yang sama sekali berbeda dari yang ditawarkan TV tradisional (Jenner, 2016).

Istilah binge watching semakin terkenal dan semakin umum di kalangan khalayak setelah muculnya layanan VOD. Istilah binge watching sudah ada sejak zaman DVD muncul, tetapi yang baru adalah cara khalayak membicarakan dan terlibat di dalamnya. Pernyataan sebelumnya diperkuat (Jenner, 2017) pada penelitian berjudul Binge Watching: Video-on-demand, quality TV and mainstreaming fandom. Istilah binge watch diterapkan pada media yang bukan TV, seperti dikemukakan Debra Ramsay. Dia tidak menonton televisi selama berjam-jam, namun menonton satu season penuh dalam satu hari saat menonton film melalui DVD. Jika dahulu istilah binge watching melekat sebagai marathon menonton film tetapi sekarang digantikan dengan marathon serial televisi. Binge-watching menyiratkan kesenangan atau kehilangan kendali (Griffee, 2013).

Menurut Shim \& Kim (2018) pada penelitian An Exploration of the Motivations for BingeWatching TV Dramas among South Korean Viewers and the Role of Individual Differences, ada lima faktor motivasi yang mendasari seseorang melakukan aktifitas binge watching, yaitu: (1) Enjoyment (termotivasi oleh keinginan untuk kesenangan dan hiburan), (2) Efficiency (termotivasi oleh keinginan untuk kepraktisan dalam mengonsumsi media), (3) Recommendation from others (termotivasi oleh keinginan untuk menghindari menonton sesuatu yang tidak menarik), (4) Perceived control (termotivasi oleh keinginan untuk memiliki kontrol atas konsumsi media), dan (5) Fendom (termotivasi oleh keinginan untuk menonton sebuah TV show karena karakter di dalamnya).

Dari kelima factor itu, hanya tiga (enjoyment, efficiency, fandom) yang berpengaruh dalam memotivasi seseorang untuk melakukan aktifitas binge watching. Penelitian Susanno, Phedra\& Murwani (2019) mengenai The determinant factors of the intention to spend more time binge-watching for Netflix Subscriber in Indonesia mengatakan ada dua niatan dasar yang terbukti berpengaruh meningkatkan niatan seseorang menghabiskan lebih banyak waktu untuk binge watching yaitu social influence dan escape from reality.

Responden ditanya apakah mereka merasa bahagia dan santai sebelum memutuskan untuk melakukan binge watching. Hasilnya menunjukkan, perasaan mereka tidak mempengaruhi niat dalam melakukan aktifitas binge watching. Di sisi lain, variabel escape from realitiy menunjukkan, mereka menonton secara berlebihan karena ingin melupakan masalah dalam kehidupan sehari-hari. 


\section{Behavioral Involvement}

Involvement atau keterlibatan pada umumnya didefinisikan dan dioperasionalkan dalam istilah sosial psikologis. Keterlibatan sosial-psikologis adalah keadaan motivasi, keinginan atau minat mengenai suatu produk, aktivitas, atau objek (Lee, 2011). Selain itu Involvement juga didefinisikan sebagai relevansi yang dirasakan seseorang dari objek berdasarkan kebutuhan, nilai, dan kepentingan yang melekat (George \& Stavros, 2013). Namun, yang lain berpendapat, involvement dapat dipahami dalam hal perilaku atau behavioral.

Behavioral involvement telah dikonsepkan dalam hal frekuensi (Mclntyre \& Pigram, 2009) dan luasnya partisipasi dalam kegiatan dan upaya yang diinvestasikan pada aktivitas yang telah direncanakan (Zabriskie \& McCormick, 2017). Mengingat tugas yang ditawarkan layanan video-ondemand relatif sedikit, maka layanan mengutamakan konsumsi konten audiovisual namun menawarkan beberapa cara untuk mengkonsumsinya.

Penelitian ini mengadaptasi penelitian Merikivi, Salovaara, Mäntymäki \& Zhang (2017) yang menggunakan variabel behavioral involvement untuk mengukur tingkat sejauh mana pelanggan terlibat dalam perilaku binge watching. Hunt, Geiger-Oneto \& Philip, (2010) juga mendefinisikan behavioral involvement sebagai sejauh mana pengguna menggunakan sistem untuk tugas tertentu yang dalam penelitian ini adalah binge-watching.

Selain itu, pengaruh dari fenomena binge watching juga perlu diperhatikan oleh pengguna. Penekanan dalam penelitian ini adalah bagaimana efek yang didapat pengguna setelah menggunakan sistem tersebut untuk aktifitas binge watching. Oleh karena itu, penelitian ini menggunakan behavioral involvement untuk mengetahui sejauh mana pengguna menggunakan sistem untuk praktik penggunaan tertentu. Praktik penggunaan behavioral involvement dalam penelitian ini adalah binge-watching. Penelitian ini mengikuti konsep perilaku binge watching sebagai praktik penggunaan yang spesifik pada suatu sistem. Seperti dijelaskan oleh Merikivi, Salovaara, Mäntymäki \& Zhang (2017), binge watching merujuk pada mengonsumsi lebih dari satu episode dari acara televisi yang sama.

\section{Iflix sebagai Layanan VOD}

Iflix merupakan salah satu layanan VOD berbayar yang menyediakan film-film layar lebar terbaru serta TV series terbaru setiap harinya. Iflix diluncurkan di Malaysia dan Filipina, Mei 2015, sebagai layanan yang setara dengan Netflix. Secara regional, Iflix ikut bersaing dengan layanan VOD lainya berbasis di Singapura yaitu, Hooq.

Pemimpin Iflix, pengusaha Patrick Grove, memperkirakan 90\% rumah tangga di ASEAN mengonsumsi konten bajakan. Grove percaya, konten Amerika yang berkualitas tinggi dibutuhkan oleh konsumen Asia Tenggara (Meese, 2016). Pada Maret 2016, Iflix melebarkan sayapnya ke Indonesia di bawah Emtek Group yang disponsori oleh Surya Citra Media. Sampai sekerang Iflix sudah me-launch kehadiranya di 10 negara di Asia Tenggara (Iflix, 2016). Mulai saat itu konten Indonesia membajari Iflix, dari film-film lama sampai film terbaru. Tidak hanya itu, Iflix juga mengeluarkan Iflix Original untuk memperkuat pasar.

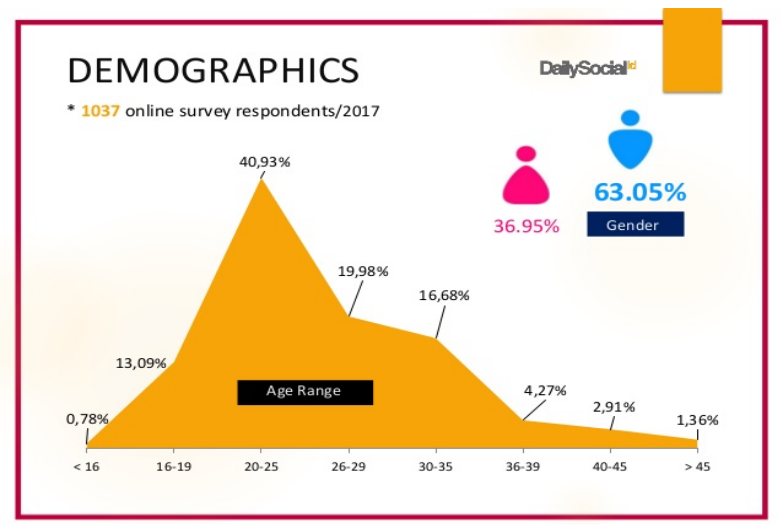

Gambar 1. Diagram demografi pengguna VOD (Zebua, 2017)

Pada Gambar 1 Daily Social.id mengadakan survei untuk melihat rata-rata demografi pengguna VOD. Hasil survey mengatakan, pengguna layanan VOD paling tinggi berusia 20-25 tahun, yaitu 
40,93\%. Hasil tersebut membuktikan, dari tahun 2017 kebanyakan anak muda dari usia $20-25$ tahun sudah tidak lagi menjadikan TV sebagai sarana mengonsumsi hiburan.

Di Indonesia pengguna video-on-demand terus meningkat setiap tahun, dan pada tahun 2018 mencapai angka 15,3 juta orang (Zebua, 2017). Iflix dan beberapa aplikasi layanan VOD lainya seperti Netflix , Hooq, dan Viu adalah aplikasi video on-demand dengan pengguna terbanyak di Indonesia (Yusuf \& Indrawati, 2019). Apalikasi layanan VOD laris ditonton karena kemudahan dan kampanye mereka atas konsep binge-watching.

\section{METODE PENELITIAN}

Penelitian ini adalah penelitian kuantitatif dengan paradigma positivisme. Metode yang digunakan adalah eksplanatif. Jenis penelitiannya survey menggunakan teknik analisis SEM (Structural Equation Model) berbasis PLS (Partial Least Square) (Andwika, Witjaksono, \& Azizah, 2020). Tujuan penelitian ini untuk melihat pengaruh motivasi binge watching terhadap behavioral involvement pada aplikasi layanan Iflix.

Teknik pengambilan sampel yang digunakan adalah non-probability sampling dengan teknik purposive sampling, yaitu pengambilan sampel yang memenuhi syarat dan kreteria tertentu (Kriyantono, 2016). Kriteria sampel yang dipilih dalam penelitian ini yakni pelanggan layanan videoon-demand Iflix yang menggunakan layanan streaming video dalam sebulan terakhir dan menonton TV shows dua episode atau lebih dalam sekali penggunaannya. Untuk mengumpulkan data primer, peneliti mendistribusikan kuesioner online menggunakan formulir Google.

Data primer dikumpulkan menggunakan kuesioner yang terdiri dari beberapa pertanyaan untuk mendapatkan jawaban dari responden (Mutaqin \& Sutoyo, 2020). Alasan peneliti menggunakan mahasiswa/mahasiswi Stikom Interstudi jurusan broadcast, karena menurut survei daily social.id layanan VOD paling tinggi digunakan oleh penonton berusia 20-25 yaitu 40,93\%.

Peneliti mengambil 105 responden dari kedua angkatan sebagai sampel yang didapat dari menggunakan rumus Isaac dan Michael dengan tingkat kesalahan sebesar 10\%. Penelitian ini mengacu pada lima motivasi binge watching yang diteliti oleh Shim \& Kim (2018) yaitu Enjoyment (4 item), Efficiency (3), Fandom (3), dan dilengkapi oleh penelitian (Susanno Phedra \& Murwani, 2019) yaitu Social influence (3 item), Escape (3) dan tiga faktor Bahavioral Involvement (Pangestu, 2019) yaitu Word of mouth intention (4 item), Attitude to use (7 item), dan Continuence to use intention (5 item).

\section{HASIL PENELITIAN}

Responden penelitian ini adalah pengguna Iflix, dan menggunakanya dalam kurun waktu sebulan terakhir serta memiliki perilaku binge watching. Tabel 1 menggambarkan profil 109 responden, 58 perempuan dan 51 laki-laki, tetapi empat orang tidak valid karena tidak memenuhi keriteria menggunakan layanan VOD Iflix.

Tabel 1. Profil Responden

\begin{tabular}{|c|c|c|c|}
\hline \multicolumn{4}{|c|}{ Profil Responden } \\
\hline & Keterangan & Frekuensi & Persentasi \\
\hline \multirow{2}{*}{$\begin{array}{c}\text { Jenis } \\
\text { kelamin }\end{array}$} & Perempuan & 58 & $53,2 \%$ \\
\cline { 2 - 4 } & Laki -laki & 51 & $46,8 \%$ \\
\hline \multirow{2}{*}{ Usia } & $<20$ tahun & 14 & $12,8 \%$ \\
\cline { 2 - 4 } & $21-25$ & 95 & $87,2 \%$ \\
\hline
\end{tabular}

Pendapatan responden perbulan sebanyak 45 orang berpenghasilan antara Rp $1.500 .000-\mathrm{Rp}$ 2.000.000, sebanyak 32 responden Rp 2.500.000 - 3.000.0000, 16 responden perbendapatan kurang dari Rp1.000.000 dan 13 responden berpendapatan di atas Rp 3.000.000. Dari total 105 responden, 27 memilih layanan non-vip atau free streaming, dan 78 responden memilih layanan premium.

Berdasarkan jawaban responden, intesitas pengguna Iflix diketahui, 50 responden atau $47.2 \%$ menggunakan Iflix 3-4 hari dalam seminggu, sebanyak 34 responden atau 32.1\% menggunakan Iflix 1-2 hari dalam seminggu. Sebanyak 14 responden atau 13.2\% menggunakan Iflix tujuh hari dalam seminggu, dan sebanyak delapan responden atau 7.5\% menggunakan Iflix 5-6 hari dalam seminggu. Untuk perangkat yang digunakan mengakses Iflix, smartphone 56.6\%, PC/Laptop 25,5\% dan 17,9\% menggunakan smart TV. 


\section{Motivasi Binge Watching}

Indikator variabel yang digunakan dalam analisis penelitian pengaruh motivasi binge watching terhadap behavioral involvement adalah valid dan realibel (Tabel 2), sehingga dapat digunakan dan cocok untuk dianalisis. Istilah dan definisi dalam penelitian ini diadaptasi dari penelitian sebelumnya. Shim \& Kim, (2018) dan Susanno Phedra \& Murwani (2019) mendefinisikan motivasi dalam konteks binge watching, sebagai: enjoyment (dimotivasi oleh keinginan untuk bersenang-senang dan hiburan), efficiency (dimotivasi oleh keinginan untuk kepraktisan dalam konsumsi media), fandom (dimotivasi oleh keinginan untuk membentuk hubungan dengan karakter media), Escape (keinginan dalam mengisi waktu luang), dan Social Influence (dimotivasi oleh keinginan untuk menghindari menonton acara yang tidak menarik dengan menghadiri umpan balik orang lain).

Hasil dari lima indikator tersebut, alpha cronbach dari setiap lima indikator bernilai positif dan lebih besar dari pada 0,60 . Outer loading di setiap indikator pada masing-masing variabel memiliki nilai di atas 0,7 .

Average Variance Extracted (AVE) juga menunjukkan nilai yang lebih tinggi dari 0,5 sehingga dapat dipastikan, seluruh indikator yang dipakai dalam penelitian ini valid. Hasil Composite Reliability (CR) juga terkonfirmasi validitasnya dengan hasil lebih besar 0,06 .

Tabel 2. Hasil Uji Validilitas \& Reliabilitas

\begin{tabular}{|c|c|c|c|}
\hline & $\begin{array}{l}\text { Cronbach's } \\
\text { Alpha }\end{array}$ & $\begin{array}{l}\text { Composite } \\
\text { Reliability }\end{array}$ & $\begin{array}{l}\text { Average } \\
\text { Variance } \\
\text { Extracted }(A V E)\end{array}$ \\
\hline $\begin{array}{l}\text { - Attitude to } \\
\text { Use }\end{array}$ & 0,903 & 0,923 & 0,632 \\
\hline $\begin{array}{l}\text { - Continuence } \\
\text { to Use }\end{array}$ & 0,848 & 0,892 & 0,623 \\
\hline - Efficiency & 0,782 & 0,873 & 0,696 \\
\hline - Enjoyment & 0,787 & 0,863 & 0,611 \\
\hline - Escape & 0,781 & 0,872 & 0,695 \\
\hline - Fandom & 0,829 & 0,898 & 0,745 \\
\hline $\begin{array}{l}\text { - Social } \\
\text { Influence }\end{array}$ & 0,766 & 0,863 & 0,677 \\
\hline $\begin{array}{l}- \text { Word of } \\
\text { Mouth }\end{array}$ & 0,827 & 0,885 & 0,659 \\
\hline
\end{tabular}

Sumber: hasil pengolahan data smart PLS 2020

\section{Behavioral Involvement}

Indikator behavioral involvement yang digunakan dalam penelitian ini diadaptasi dari penelitian sebelumnya Pangestu (2019) yang menggunakan attitude to use, continuence to use, dan word of mouth untuk mengukur sejauh mana pengguna Netflix menggunakan layanan VOD sebagai sarana binge watching. Penelitian ini, menggunakan indikator yang sama untuk mengukur sejauh mana pengguna Iflix menggunakan layanan Iflix sebagai sarana binge watching.

Dari hasil uji validilitas dan reabilitas terbukti, indikator yang digunakan dalam penelitian ini valid dan realibel (Tabel 2). Alpha cronbach dari tiga indikator menunjukan angka yang lebih besar dari 0,60. Outer loading dari setiap indikator pada masing-masing variabel menunjukan nilai di atas 0,7 . Hasil average variance extracted (AVE) menunjukkan nilai yang lebih tinggi dari 0,5 sehingga dapat dipastikan seluruh indikator yang dipakai dalam penelitian ini valid.

Hasil Composite Reliability (CR) juga terkonfirmasi validitasnya dengan hasil lebih besar 0,06. Pada Tabel 3 terlihat, nilai R-square attitude to use sebesar 0.593 atau sama dengan 59.3\%, nilai Rsquare continuence to use sebesar 0.502 atau sama dengan $50.2 \%$ dan nilai $\mathrm{R}$-square word of mouth sebesar 0.477 atau sama dengan $47.7 \%$. Hasil tersebut membuktikan, ketiga indikator tersebut secara cukup dapat dijelaskan oleh variabel independennya. 
Tabel 3. Hasil R-Square

\begin{tabular}{|c|c|c|}
\hline & $\begin{array}{c}\mathrm{R} \\
\text { Square }\end{array}$ & $\begin{array}{c}\text { R Square } \\
\text { Adjusted }\end{array}$ \\
\hline Attitude to Use & 0,593 & 0,573 \\
\hline Continuence to Use & 0,502 & 0,477 \\
\hline Word of Mouth & 0,477 & 0,450 \\
\hline
\end{tabular}

Sumber : Hasil pengolahan data Smart PLS 2020

Berdasarkan hasil pengujian statistik, diketahui enjoyment memiliki pengaruh yang positif pada attitude to use, yang berarti motivasi untuk bersenang-senang menuntun pengguna untuk menggunakan layanan Iflix. Hal ini sedikit berbeda dengan yang dijelaskan oleh Pangestu (2019) bahwa perilaku attitude to use didasarkan oleh kepuasan seseorang dalam menggunkan sebuah layanan. Namun, hasil penelitian ini selaras dengan penelitian Lestari et al., (2020) enjoyment menjadi prediktor terkuat yang membentuk sikap positif pada attitude to use.

Dengan demikian, dapat diketahui, tindakan attitude to use layanan Iflix dapat didasarkan pada kesenangan pengguna dalam menggunakan Iflix. Selanjutnya diketahui, enjoyment memiliki pengaruh positif terhadap continuence to use. Hal ini selaras dengan penelitian Nguyen (2015), enjoyment secara langsung mendorong pengguna melakukan continuence to use, dalam arti lain dengan kesenangan yang didapatkan pengguna dapat menimbulkan keberlanjutan dalam menggunakan layanan Iflix untuk sarana binge watching. Enjoyment memiliki pengaruh positif terhadap word of mouth, hal ini menunjukan, kesenangan yang didapat pengguna dapat menimbulkan word of mouth positif terhadap layanan Iflix.

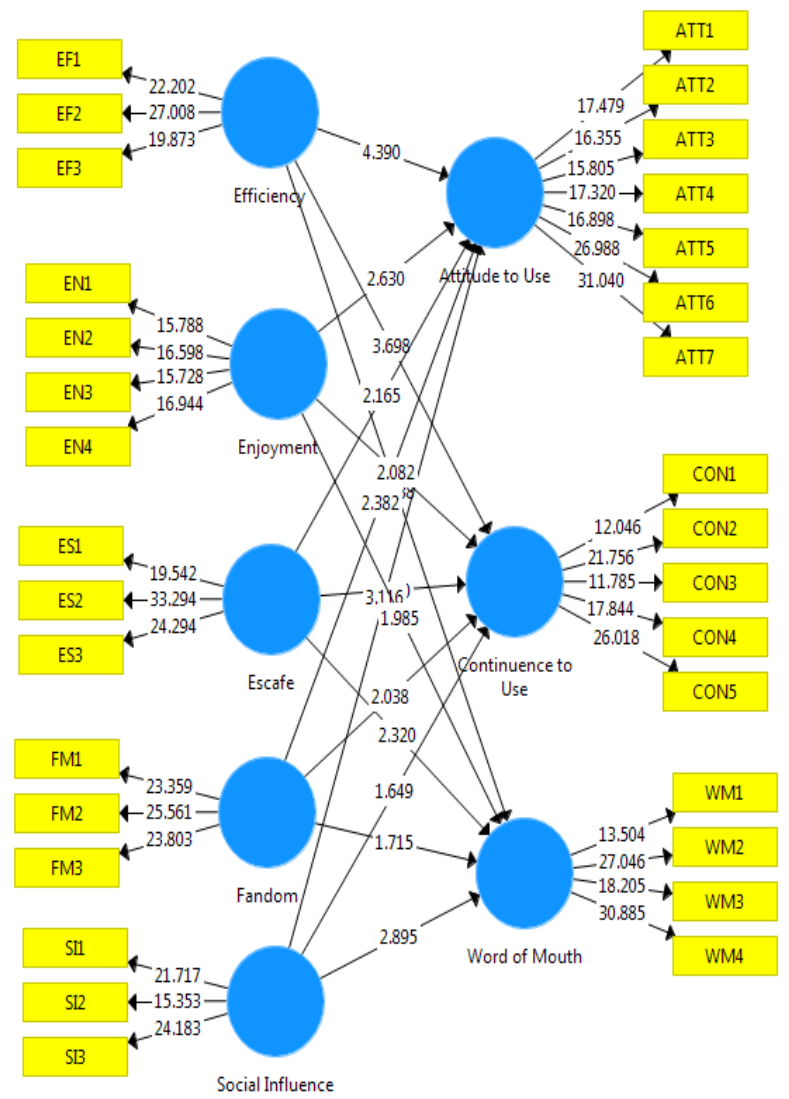

Gambar 2. Model SEM

Dari hasil pengujian statistik terbukti, efficiency berpengaruh positif terhadap attitude to use Hal ini selaras dengan penelitian Fernández-Manzano et al., (2016), kepraktisan dalam menggunakan media mendorong pengguna melakukan attitude to use, yang dalam penelitian ini adalah layanan Iflix. 
Selain itu efficiency terbukti berpengaruh positif pada continuence to use, dengan keinginan terhadap kepraktisan dapat menimbulkan rasa ketergantungan untuk menggunakan media tersebut, serta efficiency memiliki pengaruh positif terhadap word of mouth, kepraktisan dapat menimbulkan word of mouth positif terhadap layanan Iflix sebagai sarana binge watching.

Dalam hasil uji statistik diketahui, fandom memiliki pengaruh poitif yang signifikan terhadap attitude to use. Hal ini menjelaskan bahwa adanya aktris/aktor/karakter tertentu dalam sebuah tayangan TV shows mampu memberikan pengaruh kepada pengguna untuk menggunakan layanan VOD sebagai sarana binge watching. Berkaitan dengan attitude to use, Hills (2018) mendefinisikan fandom sebagai sebuah fans yang terbetuk dari sebuah tindakan menonton sebuah TV shows atau ketegangan antara karakter lingkungan media yang saling terhubung pada sebuah gagasan pengalaman audiens.

Fandom juga terbukti memiliki pengaruh yang positif pada continuence to use jika dikaitkan dengan adanya aktor/aktris/karakter tertentu, membuat pengguna menggunakan layanan Iflix. Setelah itu terjadilah perilaku continuence to use untuk kembali menggunakan layanan Iflix sebagai sarana binge watching. Tetapi menurut hasil path analisis, fandom terbukti tidak memiliki pengaruh positif terhadap word of mouth. Ini bisa diartikan, walaupun pengguna kembali menggunakan layanan iflix untuk sarana binge watching, dengan hadirnya aktor/aktris/karakter tertentu, tidak memberi jaminan pengguna akan memberikan word of mouth yang positif terhadap tayangann TV shows tersebut.

Hasil uji statistik menunjukan, social influence terbukti berpengaruh positif terhadap attitude to use dan continuence to use, dapat disimpulkan dengan pengaruh sosial atau pengaruh orang sekitar membuat pengguna cenderung percaya bahwa penggunaan teknologi seperti layanan iflix dapat memberikan keuntungan bagi mereka dan nilai serupa (Cristobal Fernandez-Robin, Scott McCoy, Diego Yanez, 2019). Tetapi pada hasil path analisis social influence terbukti tidak memiliki pengaruh positif terhadap word of mouth. Hal tersebut membuktikan, social influence tidak mempengaruhi word of mouth.

Dimensi terakhir adalah dimensi escape yang menurut hasil statistik memiliki pengaruh positif terhadap attitude to use, cotinuence to use, dan word of mouth. Dapat disimpulkan, escape from reality berpengaruh pada sikap pengguna dalam memilih menggunakan layanan iflix. Keinginan pengguna untuk melarikan diri dari kehidupan nyata mempengaruhi motivasi pengguna untuk melanjutkan menggunakan Iflix, dan selanjutnya escape dapat menghasilkan word of mouth yang positif.

Tabel 4. Hasil Uji Hipotesis

\begin{tabular}{|l|c|c|c|c|c|c|}
\hline & $\begin{array}{l}\text { Original } \\
\text { Sample }\end{array}$ & Sample Mean & $($ STDEV) & T Statistics & P Values & Result \\
\hline EF -> ATT & 0,309 & 0,315 & 0,070 & 4,390 & 0,000 & Supported \\
\hline EF -> CON & 0,309 & 0,313 & 0,084 & 3,698 & 0,000 & Supported \\
\hline EF -> WOM & 0,216 & 0,214 & 0,088 & 2,438 & 0,015 & Supported \\
\hline EN -> ATT & 0,194 & 0,194 & 0,074 & 2,630 & 0,009 & Supported \\
\hline EN -> CON & 0,161 & 0,162 & 0,077 & 2,082 & 0,038 & Supported \\
\hline EN -> WOM & 0,162 & 0,163 & 0,082 & 1,985 & 0,048 & Supported \\
\hline ESP -> ATT & 0,164 & 0,166 & 0,076 & 2,165 & 0,031 & Supported \\
\hline ESP -> CON & 0,247 & 0,252 & 0,084 & 2,930 & 0,004 & Supported \\
\hline ESP -> WOM & 0,191 & 0,198 & 0,082 & 2,320 & 0,021 & Supported \\
\hline FD -> ATT & 0,182 & 0,183 & 0,076 & 2,382 & 0,018 & Supported \\
\hline FD -> CON & 0,157 & 0,153 & 0,077 & 2,038 & 0,042 & Supported \\
\hline FD -> WOM & 0,147 & 0,143 & 0,086 & 1,715 & 0,087 & Not Supported \\
\hline SI -> ATT & 0,253 & 0,246 & 0,081 & 3,116 & 0,002 & Supported \\
\hline SI -> CON & 0,141 & 0,140 & 0,086 & 1,649 & 0,100 & Not Supported \\
\hline SI -> WOM & 0,272 & 0,268 & 0,094 & 2,895 & 0,004 & Supported \\
\hline
\end{tabular}

Sumber: Hasil pengolahan data Smart PLS 2020

\section{KESIMPULAN}

Penelitian ini bukanlah penelitian pertama yang membahas mengenai dasar motivasi dari perilaku binge watching yang dikonsepkan sebagai behavioral involvement, tetapi penelitian ini merupakan penelitian pertama yang menjadikan layanan video on-demand Iflix sebagai subjek penelitiannya. Penelitian ini membahas tentang faktor-faktor yang mempengaruhi pengguna untuk melakukan binge watching menggunakan layanan VOD Iflix. 
Dari hasil analisis faktor-faktor yang mempengaruhi motivasi binge watching terhadap behavioral involvement, diperoleh hasil enjoyment, efficiency, dan escape berpengaruh kepada ketiga indikator behavioral involvement yaitu word of mouth, attitude to use, continuence to use, sedangkan social influence terbukti tidak memiliki pengaruh terhadap continuence to use dan fandom tidak memiliki pengaruh terhadap word of mouth.

Penelitian ini dapat dikembangkan dengan memperluas populasi agar mencakup sampel yang lebih banyak dan hasil yang lebih beragam serta signifikan atau ditinjau lebih dalam dengan merubah subjek penelitian dengan layanan VOD lain untuk mengungkap faktor faktor lain yang belum dapat peneliti ungkap pada penelitian ini.

\section{DAFTAR PUSTAKA}

Andwika, V. R. ., \& Witjaksono, R. W. . (2020). Analysis of User Acceptance of ERP System on After Sales Function Using Unified Theory of Acceptance and Use of Technology (UTAUT) Model. International Journal of Advances in Data and Information Systems, 1(1), 26-33. https://doi.org/10.25008/ijadis.v1i1.178

APJII. (2019). Penetrasi dan Profil Perilaku Pengguna Internet Indonesia Tahun 2018. APJII, 51. www.apjii.or.id

Cristobal Fernandez-Robin, Scott McCoy, Diego Yanez, R. H.-S. (2019). Netflix, Who Is Watching Now? In Lecture Notes in Computer Science (including subseries Lecture Notes in Artificial Intelligence and Lecture Notes in Bioinformatics): Vol. 11578 LNCS. https://doi.org/10.1007/9783-030-21902-4_35

Eka, R. (2015). Video on Demand. Daily Social IDhttps://Dailysocial.Id/Post/Video-on-Demand-DanPenerimaannya-Oleh-Masyarakat-Indonesia. https://dailysocial.id/post/video-on-demand-danpenerimaannya-oleh-masyarakat-indonesia

Fernández-Manzano, E. P., Neira, E., \& Clares-Gavilán, J. (2016). Data management in audiovisual business: Netflix as a case study. Profesional de La Informacion, 25(4), 568-576. https://doi.org/10.3145/epi.2016.jul.06

George, T., \& Stavros, T. (2013). The Role of Psychological Commitment and Attitudinal Loyalty on The Relationship between Involvement and Behavioral Loyalty of Sport Fans. The Sport Journal, 1999, 1-16. http://thesportjournal.org/article/the-role-of-psychological-commitment-andattitudinal-loyalty-on-the-relationship-between-involvement-and-behavioral-loyalty-of-sportfans/

Griffee, S. (2013). Netflix, 'binge-watching' shift TV-viewing habits.

Hills, M. (2018). Netflix, transfandom and 'trans TV': Where data-driven fandom meets fan reflexivity. Critical Studies in Television, 13(4), 495-498. https://doi.org/10.1177/1749602018797738

Hirsen, J. (2015). Cable in trouble over streaming Cable in trouble over streaming. Newsmax. https://www.newsmax.com/Hirsen/Cable-Streaming-HBO-ratings/2015/03/16/id/630328/

Hunt, D. M., Geiger-Oneto, S., \& Philip E Varca. (2010). Satisfaction In The Context Of Customer CoProduction: A Behavioral Involvement Perspactive. 19, 56-57.

Iflix.

https://www.iflix.com/?gclid=CjwKCAiAws7uBRAkEiwAMlbZjjTn4LfDJ5XtAhXWSnK6rJjm 1ly_T2rh8Y3LRQHobBG-csLZqwWLchoCYXwQAvD_BwE

Jenner, M. (2016). Is this TVIV? On Netflix, TVIII and binge-watching. New Media and Society, 18(2), 257-273. https://doi.org/10.1177/1461444814541523

Jenner, M. (2017). Binge-watching: Video-on-demand, quality TV and mainstreaming fandom. International Journal of Cultural Studies, 20(3), 304-320. https://doi.org/10.1177/1367877915606485

Kriyantono, R. (2016). Sampling. Riset Komunikasi (pp. 158-159). Kencana Prenada Media Group.

Lee, T. H. (2011). How recreation involvement, place attachment and conservation commitment affect environmentally responsible behavior. Journal of Sustainable Tourism, 19(7), 895-915. https://doi.org/10.1080/09669582.2011.570345

Lesley Lissath Pena. (2015). Breaking Binge: Exploring The Effects Of Binge Watching On Television Viewer Reception. June. https://surface.syr.edu/etd/283

Lestari, E. D., Richard, O., \& Soesanto, C. (2020). Implications on Continuance Intention To Use Svod: Study on. 15(2). 
Mclntyre, N., \& Pigram, J. J. (2009). Recreation specialization reexamined: The case of vehicle-based campers. https://doi.org/https://doi.org/10.1080/01490409209513153

Meese, J. (2016). Edited By Ramon Lobato and Global Video.

Merikivi, J., Salovaara, A., Mäntymäki, M., \& Zhang, L. (2017). On the way to understanding binge watching behavior: the over-estimated role of involvement. https://doi.org/https://doi.org/10.1007/s12525-017-0278-x.

Mutaqin, K. A., \& Sutoyo, E. (2020). Analysis of Citizens Acceptance for e-Government Services in Bandung, Indonesia: The Use of the Unified Theory of Acceptance and Use of Technology (UTAUT) Model. Bulletin of Computer Science and Electrical Engineering, 1(1), 19-25. https://doi.org/10.25008/bcsee.v1i1.3

Nguyen, D. (2015). Understanding Perceived Enjoyment and Continuance Intention in Mobile Games. ICFAI Journal of Systems, 58. http://epub.lib.aalto.fi/fi/ethesis/pdf/14000/hse_ethesis_14000.pdf

Pangestu, G. H. (2019). Analisis Behavioral Involvement Pada Binge-Watching (Studi Pada Layanan Video-on-Demand Netflix).

Romli, M., \& Syamsul, A. (2012). Jurnalistik Online: Jurnalistik Masa Depan. Nuansa Cendekia Rosdakarya.

Shabrina, V. G. (2019). Pengaruh Revolusi Digital terhadap Pemasaran dan Perilaku Komsumen, Jurnal Pewarta Indonesia. 1(2), 131-141.

Shim, H., \& Kim, K. J. (2018). An exploration of the motivations for binge-watching and the role of individual differences. In Computers in Human Behavior (Vol. 82). Elsevier B.V. https://doi.org/10.1016/j.chb.2017.12.032

Sodano, T. M. (2012). Television's Paradigm (time) Shift In Time. In M. Ames (Ed.), Time in Television Narrative: Exploring Temporality in Twenty-First-Century Programming. University Press Of Mississippi.

Stenovec, T. (2015). We're about to pass a watershed moment in the decline of TV. Business Insider. https://www.businessinsider.com/streaming-will-soon-pass-traditional-tv-20159? $\mathrm{IR}=\mathrm{T} \& \mathrm{r}=\mathrm{US} \& \mathrm{IR}=\mathrm{T}$

Susanno, R., Phedra, R., \& Murwani, I. A. (2019). The determinant factors of the intention to spend more time binge-watching for Netflix Subscriber in Jakarta. 10(3), 807-812.

Wagner, C. N. (2016). "Glued to the Sofa": Exploring Guilt and Television Binge-Watching Behaviors. http://digitalcommons.trinity.edu/comm_honors/11

Wahanani, H. E., Saputra, W. S. J., \& Freitas, E. M. F. (2018). Performance analysis of video on demand and video streaming on the network MPLS Traffic Engineering. International Journal of GEOMATE, 15(50), 141-148. https://doi.org/10.21660/2018.50.IJCST33

Yusuf, N. A., \& Indrawati. (2019). Analisis Faktor Yang Memengaruhi Pembentukan Minat Berlangganan Di Industri Video-on-Demand Di Indonesia. 3(1), 2565-2568.

Zabriskie, R. B., \& McCormick, B. P. (2017). Parent and Child Perspectives of Family Leisure Involvement and Satisfaction with Family Life. Journal Of Leisure Researc, 3(2), 163-189. https://doi.org/https://doi.org/10.1080/00222216.2003.11949989

Zebua, F. (2017). Laporan DailySocial: Survei Video on Demand 2017. https://dailysocial.id/post/laporan-dailysocial-survei-video-on-demand-2017 